\title{
Influence of Metal Oxide Additives on Cotton Seed Biodiesel Fueled In CI Diesel Engine
}

\author{
A. Pakiya pradeep, S. Gowthaman
}

\begin{abstract}
Biodiesel is a standout amongst the most encouraging sustainable, elective and ecologically well disposed bio fuels that can be utilized in diesel engine without any modification. The exploratory work has been led on a four-chamber, four - stroke, direct infusion (DI) diesel motor. In this examination, biodiesel (Produced from cotton seed oil by transesterification procedure) and typical diesel have been utilized as a reference fuel. In this examination, two diverse nanoparticle fuel added substances in particular $\mathrm{MgO} 2$ and $\mathrm{CeO} 2$ were added to biodiesel at the option measurement of 250 and 500ppm. An experimental analysis of performance and emission for present of metal oxide nano-particles with cotton seed biodiesel used as a fuel in CI diesel engine and also optimized the quantity of dosing metal oxide can be effective for better performance. In this investigation could be done with present and absent of metal oxide additives are likewise displayed. The present of $\mathrm{MgO} 2$ nano-particles has been increased the flash point and viscosity of the biodiesel. It was clearly noticed that the Expansion of $\mathrm{MgO} 2$ nanoparicles resulted lower HC and NOx outflows.
\end{abstract}

Keywords:Metal oxides, Biodiesel, CI engine, Low combustion temperature, Low NOx and smoke emissions.

\section{INTRODUCTION}

The Compression ignition engines are generally utilized in automobile sector, because of its dependable activity and economy. As the oil stores are draining at a quicker rate because of the development of populace and the resulting vitality use, a critical requirement for scan for an inexhaustible elective fuel emerge. Additionally, the danger of a worldwide temperature alteration and the stringent government guideline made the motor makers and the buyers to pursue the emanation standards to spare nature from contamination. As of late, stringent discharge enactment has been forced worldwide on the oxides of nitrogen (NOx), and smoke and particulate issue produced from car diesel motors.

Revised Manuscript Received on December 5, 2019

* Correspondence Author

A. Pakiya pradeep, Research Scolar, Department of Automobile Engineering, Kalasalingam Academy of Reasearch and Education, Krishnankoil, Srivilliputtur, Tamilnadu, India. Email: igneshpradeep@gmail.com

S. Gowthaman*, Associate professor, Department of Automobile Engineering, Kalasalingam Academy of Reasearch and Education, Krishnankoil, Srivilliputtur, Tamilnadu, India. Email: gowthammech@hotmail.com
In light of test examinations, Guru et al. [1] found that manganese $(\mathrm{Mn})$ added substances has more noteworthy impact on diesel fuel properties like lessening the point of solidification, streak point, consistency and expanded cetane number. What's more, that different added substances like cupper, magnesium and calcium has least impact on diesel fuel properties than manganese. It was seen from the outcomes for diesel with $\mathrm{Mn}$ added substance were conveyed lower motor surge of $\mathrm{O} 2$ and $\mathrm{CO}$ about $0.2 \%$ and $14.3 \%$, separately. While at SO2 discharge could be diminished and from these all impacts can be expanded the net working effectiveness up to $0.8 \%$. Valentine et al. [2] demonstrated that the bimetallic platinum/cerium added substances with diesel fuel can be emanates lower measure of $\mathrm{HC}, \mathrm{CO}$, sediment discharge and without shifting NOx outflows. The economy of fuel regularly expanded for both hard core and light obligation fast diesel motors. The present contaminant of oxygen in the diesel fuel had been improved the oxidation of fuel particles, which came about lower smoke discharge and higher NOx emanation [3]. In whole of metal oxides like copper, iron, cerium and cobalt have been broadly utilized as fuel included substance with energizes. The effect of cerium on the size conveyance and sythesis of diesel particulate issue has been examined by Skill as et al.[4] and it was seen that the lower size of $10 \mathrm{~nm}$ width cerium particles can adequately diminish the motor discharge. Lahaye et al. [5] considered the impact of cerium oxide on arrangement of ash from the examination of warm debasement and oxidative warm corruption strategy. From this considered, it was seen that the few measure of sediment tests are oxidized and unequivocally lessen the start temperature of ash. This as a result of essence of oxygen content in the Ce (cerium oxide).

Jung et al. [6] contemplated the impact $\mathrm{Ce}$ added substance on ultra-fine molecule of diesel discharge and oxidation energy. The tried outcomes demonstrated that decrease the centralization of pinnacle number during the collection mode, degrease the light off temperature and without influencing the initiation vitality. Regardless of the way that the rate of oxidation extended quite with the extension of $\mathrm{Ce}$ with diesel fuel and found that the amount of dosing has very little impact [7,8]. Escribano et al., [9] considered the helper and morphological depiction of a $\mathrm{Ce}$ $\mathrm{Zr}$ mixed oxide maintained Mn oxide similarly as on its synergist activity in the oxidation of particulate issue rising up out of diesel motors. $\mathrm{Mn}-\mathrm{Ce}-\mathrm{Zr}$ force shows high development in the buildup 
oxidation making $\mathrm{CO}$ and furthermore $\mathrm{CO}$ as a reaction in the range $152-452^{\circ} \mathrm{C}$. Barry park et al [10] studied the utilization $\mathrm{CeO}_{2}$ nano-particles with diesel fuel was peril and danger during examination.

Ying et al. 2006[11] explored many oxygenates are practical in decreasing transmissions from diesel motors. A segment of the investigates have been based on fuel added substances to decrease hazardous releases. Fuel properties are made by using a couple added substances to improve start adequacy and to decrease poison surges. One of those additional substances is metallic based blends, which have been used as consuming driving force for hydrocarbon powers. Keskin et al. [12] communicated that effects of the metallic-put together added substances with respect to fuel use and exhaust outpourings of diesel motor were investigated. The metallic-based included substances were conveyed by mixing of gum destructive (abietic destructive) with $\mathrm{MnOx}$ or $\mathrm{MgO}_{2}$. In this test fuel preparation method those metal additives are doped with diesel fuel in the form of $8 \mu \mathrm{mol} / \mathrm{l}$ and $16 \mu \mathrm{mol} / \mathrm{l}$. The two included substances could be increased the characteristics of diesel fuel like instance, consistency, streak point, cloud and pour point. Invigorates present and missing of included substances were attempted in a prompt imbuement diesel engine at maximum load stipulation. The experimental investigation of metallic based additives ( $\mathrm{Mn}$ and $\mathrm{Mg}$ ) utilized in diesel engine has indicated that $\mathrm{Mn}$ additive consume less fuel consumption is about $4.16 \%$ than $\mathrm{Mg}$. Additive of $\mathrm{Mn}$ with diesel can able to reduction of smoke by $29.82 \%$ and $\mathrm{CO}$ by $16.35 \%$. In addition, that the present of oxygen content in the additive leads to higher oxidation of fuel resulted increased NOx (Keskin et al., 2010).

Escribano et al. [13] have been contemplated the individual fuel trademark, the motor execution and surge for expansion of metal oxide nano particles with and without diesel fuel and the further more examined on expansion of dosing sum. The fresh temperature attributes of diesel didn't display huge variety, because of the improvement of cerium oxide nano- particles. In pressure start diesel motor utilized biodiesel with various dosing dimension of metal oxide ( $\mathrm{CeO} 2$ ) from

$20 \mathrm{ppm}$ to $80 \mathrm{ppm}$ were shows an improvement in the gainfulness of the motor and its obviously seen that the decrease of NOx and HC [14-15]. This in light of the present of Cerium oxide nano-particles came about lower impact point and the thickness of biodiesel. The reason for this examination is to research impacts of nanoparticle included substances explicitly $\mathrm{MnO} 2$ and $\mathrm{CeO} 2$ at various dosing levels ( 250 and $500 \mathrm{ppm}$ ) to the biodiesel (cotton seed methyl ester) fuel for progression of the exhibition and outflows in a CI Engine.

\section{EXPERIMENTAL SETUP}

The test examinations were finished in two phases. In the first arrange, the diverse physicochemical characteristics of changed bio diesel were settled and appeared differently in relation to petroleum derivatives. The properties examined were the point of ignition, fire, cloud, pour and consistency. Standard ASTM test methodology was utilized in the analyses. In the second stage, broad execution tests were led on a solitary chamber CI engine utilizing the modified and base powers, so as to assess the motor execution just as the discharge attributes utilizing a fumes gas emanation analyzer. The strategy for arrangement of the powers with the added substance nano- particles alongside the test techniques for acquiring the fu9el characteristics and the subtleties of the exhibition test office are altogether introduced beneath.

\section{A. Arrangement of Modified Fuels.}

The transfection method was produce biofuel of cotton seed methyl ester from the cotton seed oil. Fuel characteristics are indicated in the table Table 1, as monetarily available nano-particle size of 10 to 30 nanometers. The amount of dosing nano-particle tests (by weight) in the base fuel was 250 and $500 \mathrm{ppm}$. The nanoparticle test required for the measure of each dosing measurement was evaluated by using a precision electronic balance and mixed with the fuel by strategies for a ultrasonic shaker, applying an enduring fomentation time of 30 minutes to make a uniform suspension. The modified fuel

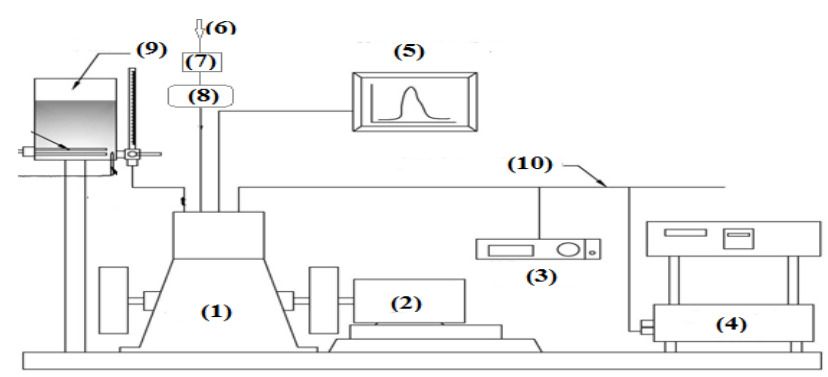

$$
\begin{aligned}
& \text { 1. Kirlosker TV-1 Engine } \\
& \text { 2. Loading device } \\
& \text { 3. AVL Five gas Analyser } \\
& \text { 4. AVL Smoke meter }
\end{aligned}
$$

6. Air inlet
7. Air Filter

8. Air Stabilizing tank

9. Fuel Tank

10. Exhaust gas pipe line

was utilized after arranging, in order to keep up a vital separation from any settling or for sedimentation to occur.

\section{Fig.1 Experimental Setup}

\section{B. Assurance of Fuel Properties}

The point of flash, fire, pour, cloud and consistency were estimated by utilizing standard test strategies. The thickness of fuel had been estimated utilizing the Redwood viscometer. Ignition and fire point can be measured by Cleveland open cup apparatus and a standard cloud and pour point mechanical assembly was utilized for estimating the cloud and pour focuses. The energizes properties are appeared table 1

\section{Portrayal of the Test Engine}

In the performance and spread esca mines, a four stroke single slot, water cooled CI engine was used. An ordinary persistent speed weight trials were furthermore performed on the engine. In eddy current dynamometer was used for slaking the motor, which specifications are given in the Table 2, and a graphic square 
diagram of the preminary test offices plot in figure 1

Table: 1 Properties of Fuel

\begin{tabular}{|c|c|c|c|c|c|c|}
\hline \multirow{2}{*}{ PROPERTIES } & \multirow[b]{2}{*}{ 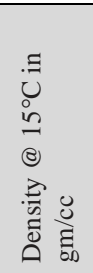 } & \multirow[b]{2}{*}{ 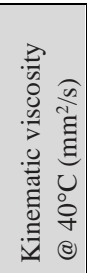 } & \multirow[b]{2}{*}{ 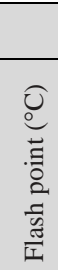 } & \multirow[b]{2}{*}{$\begin{array}{l}0 \\
0 \\
0 \\
0 \\
0 \\
0 \\
0 \\
0 \\
0\end{array}$} & \multirow[b]{2}{*}{ 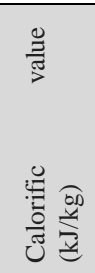 } & \\
\hline & & & & & & 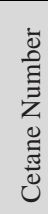 \\
\hline DIESEL & 0.8344 & 3.07 & 60 & 69 & 44125 & 51 \\
\hline BIODIESEL & 0.8835 & 6.83 & 150 & 161 & 39292 & 52 \\
\hline $\begin{array}{l}\mathrm{CME}+\mathrm{CeO} 2 \\
25 \mathrm{ppm}\end{array}$ & 0.8722 & 6.91 & 155 & 161 & 39288 & 52 \\
\hline $\begin{array}{l}\mathrm{CME}+\mathrm{CeO} 2 \\
50 \mathrm{ppm}\end{array}$ & 0.8592 & 6.98 & 162 & 161 & 39247 & 52 \\
\hline $\begin{array}{l}\mathrm{CME}+\mathrm{ZnO} \\
25 \mathrm{ppm}\end{array}$ & 0.8724 & 6.91 & 155 & 161 & 39288 & 52 \\
\hline $\begin{array}{l}\mathrm{CME}+\mathrm{ZnO} \\
50 \mathrm{ppm}\end{array}$ & 0.8594 & 6.98 & 162 & 161 & 39247 & 52 \\
\hline
\end{tabular}

Table 2: Engine Specification

\begin{tabular}{|l|l|}
\hline Make & KirloskarTV-1 Engine \\
\hline Type & $\begin{array}{l}\text { Single cylinder vertical water } \\
\text { cooled 4-stroke Diesel Engine }\end{array}$ \\
\hline Bore X Stroke & $87.5 \mathrm{~mm} \mathrm{X} 110 \mathrm{~mm}$ \\
\hline Compression ratio & $17.5: 1$ \\
\hline Fuel & Diesel \\
\hline Rated Brake Power & $5.2 \mathrm{~kW}(7 \mathrm{HP})$ \\
\hline Speed & $1500 \mathrm{rpm}$ \\
\hline Ignition timing & $23^{\circ} \mathrm{BTDC}(\mathrm{rated})$ \\
\hline Injection Pressure & $220 \mathrm{kgf} / \mathrm{cm}^{2}$ \\
\hline Loading Device & Eddy current dynamometer \\
\hline Orifice Diameter & $0.02 \mathrm{~m}$ \\
\hline Dynamometer arm length & $0.195 \mathrm{~m}$ \\
\hline
\end{tabular}

\section{RESULT AND DISCUSSION}

The essential goal of this examination is to decide the variety because of the expansion of $\mathrm{MnO} 2$ and $\mathrm{CeO} 2$ Nano-particles, to evaluate the impact of the dimension of consideration of the added substances (dosing quantity) on the varieties. Execution trials are directed on the single chamber CI diesel engine utilizing the biodiesel fuel tests and contrasted and those with the base line diesel, to decide the engine execution upgrade and the decrease of emanations because of the expansion of impetus. In light of the exploratory outcomes, the varieties in the effectiveness and discharges of the CI motor utilizing the adjusted fills are resolved with different dosing level.

\section{A. Engine Performance}

In this figure 2 have been demonstrated that the variety of brake warm productivity (BTE) by use of standard and altered bio fuel. Higher BTE can be filed by expansion of $\mathrm{MnO} 2$ with diesel. Present of $\mathrm{MnO} 2$ in the fuel were expanded the start slack and complete burning, because of the defilement of oxygen. As appurtenance of $\mathrm{CeO} 2$ present with biodiesel fuel has extend the proficiency in light of oxygen cradle. Thusly a higher brake warm productivity of
$5 \%$ can be accomplished by expanded the dimension of dose from $250 \mathrm{ppm}$ to $500 \mathrm{ppm}$. The use $\mathrm{CeO} 2$ with biodiesel fuel has improved the oxidation of carbon particles inciting an efficient activity.

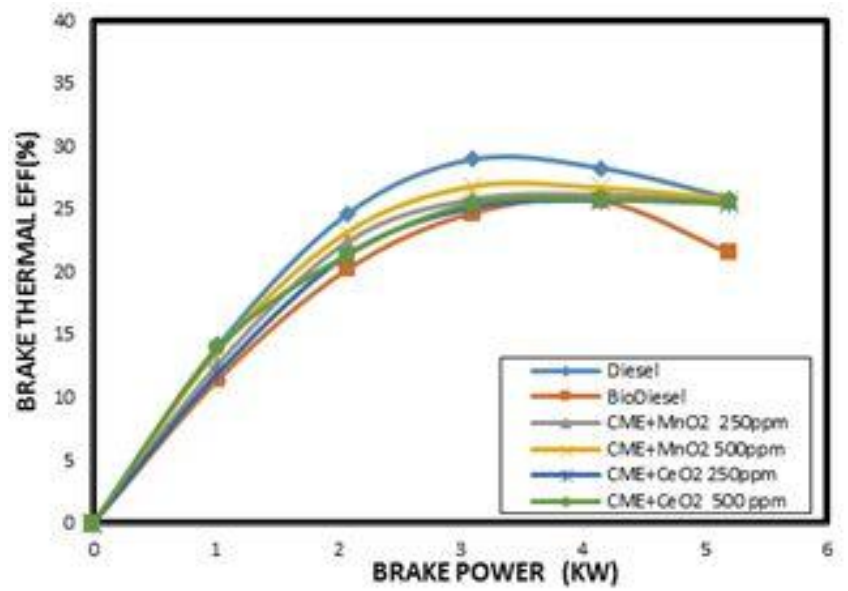

Figure 2. Variation of BTE with BP for various biodiesel blends

In figure 3 showed that the variety of explicit fuel utilization (SFC) with Brake control (BP) concerning different of metal oxide added substances present in the diesel fuel. Brake power regards normally extended with the extension of both $\mathrm{Ce}$ and Mn oxide added substances with bio energizes. Most extreme burden condition the fuel utilization is to be expanded for metal added substances. This as a result of balanced energies at the nano-particles development while at motor worked under cotton seed methyl ester (CSME). The most outrageous brake control increase as shown by CSME fuel result is 38 $\%$ and $4.6 \%$ for Increased the nano-molecule of 250 and 500 ppm CeO2, 6.6\% and $4.2 \%$ for the 250 and 500 ppm $\mathrm{MnO} 2$ independently. The best typical brake control addition is $2.4 \%$ as demonstrated by base fuel (CSME fuel) at the development portion of $250 \mathrm{ppm} \mathrm{MnO} 2$.

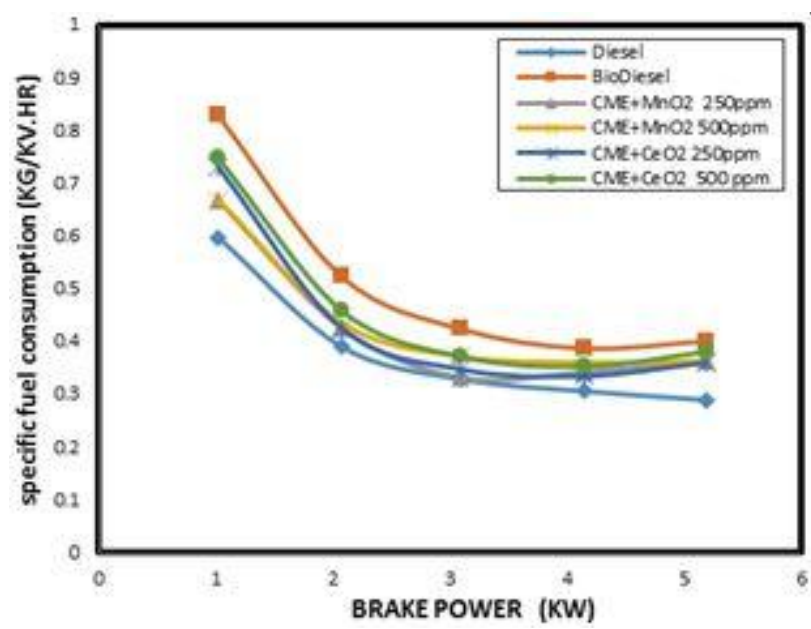

Fig 3.Variation of SFC with BP for various biodiesel Blends

\section{B. Discharge Characteristics}

A transmission analyzer has been assessed the hydrocarbon (HC) outflow for the different motor fuel like diesel, cotton 
seed methyl ester and its metal added substance powers.

In figure 4 demonstrates that the grouping of $\mathrm{HC}$ discharges for CSME with different measure of dosing $\mathrm{CeO} 2$ and $\mathrm{MnO} 2$. It was seen that the $\mathrm{HC}$ flood altogether diminished because of the present of oxygen part in the metal additive's. In CI motor the nearness of lean or rich blend and low burning temperature are the purpose behind produce unburned hydrocarbon outflow (HC). The fumes discharge is containing unique fuel particles and mostly oxidized hydrocarbons. HC flood supposedly is significantly diminished on the augmentation of the extra substance. Cerium oxide can experience a change from the Stoichiometric $\mathrm{CeO} 2(+4)$ "valance state to the $\mathrm{Ce}(+3)$ state through an honorably low-essentialness response. Cerium oxide supplies the oxygen for the decay of the hydrocarbon likewise as the development and gets changed over to cerium oxide $(\mathrm{Ce})$ as looks for after.

Cerium oxide $(\mathrm{CeO})$ as an oxidation force in like manner cuts down the carbon start activation temperature and along these lines overhauls $\mathrm{HC}$ oxidation, propelling complete hydrocarbon radiations was secured for included substance dosing sum changes from 250 to $500 \mathrm{ppm}$ of the extra substance. Wisdom has been made on the component of the NO transmissions from bio diesel, in the unadulterated structure and in the modified structure. On account of its high warm unfaltering quality, $\mathrm{Ce}$ molded from the oxidation of hydrocarbon and dregs remains dynamic in the wake of overhauling the fundamental consuming cycle and gets deoxidized to $\mathrm{CeO}$ through the lessening of nitrogen oxide.

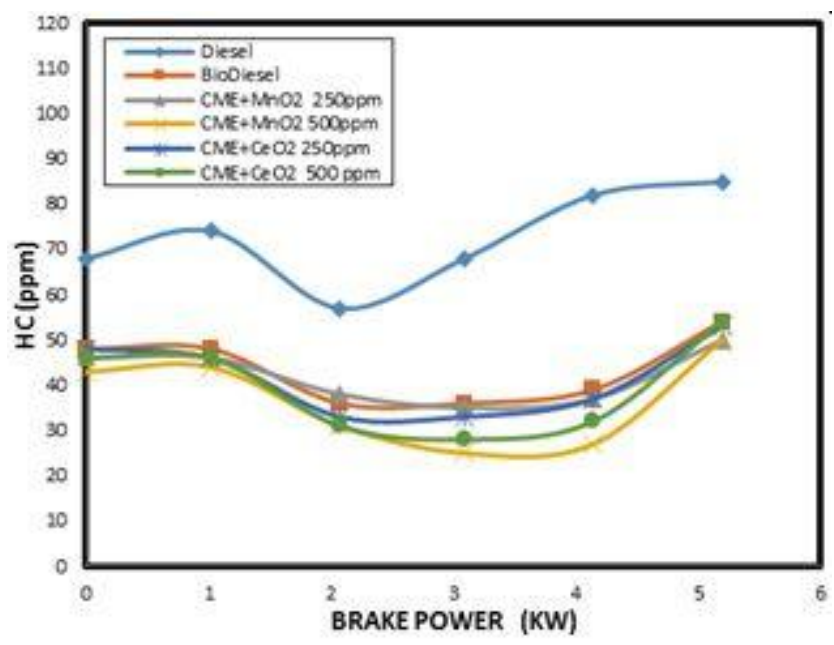

Figure 4. Variation of $\mathrm{HC}$ with $\mathrm{BP}$ for various biodiesel blends

Nitrogen oxides (NO) created by oxidation inside the chamber at temperature of $1927^{\circ} \mathrm{C}$. Subsequently the NOx arrangement is relied upon the oxygen content in the fuel and chamber temperature. In figure 6 found that the NOx radiation, exactly as expected, is influenced by the extension of the $\mathrm{CeO} 2$ nano-particles in CSME bio energizes. It very well may be seen that the NOx outpouring usually degreased on the development of $\mathrm{CeO} 2$ nano- particles with biodiesel, as showed up in Figure 5, where a typical decrease of NOx is around $33 \%$, while a dosing measurement of $250 \mathrm{ppm}$ consuming. A commonplace lessening of $24 \%$ to $38 \%$ in the

for $\mathrm{CeO} 2$ nano-particles than biodiesel. At the point when all is said in done, there is a reduction in NOx transmission on account of the development of cerium oxide could be watched the warmth during depleted, which came about lower burning temperature. An extension of $\mathrm{CeO} 2$ with biodiesel came about expanded oxidation of fuel particles prompts higher ignition temperature and higher NOx outpouring than diesel fuel.

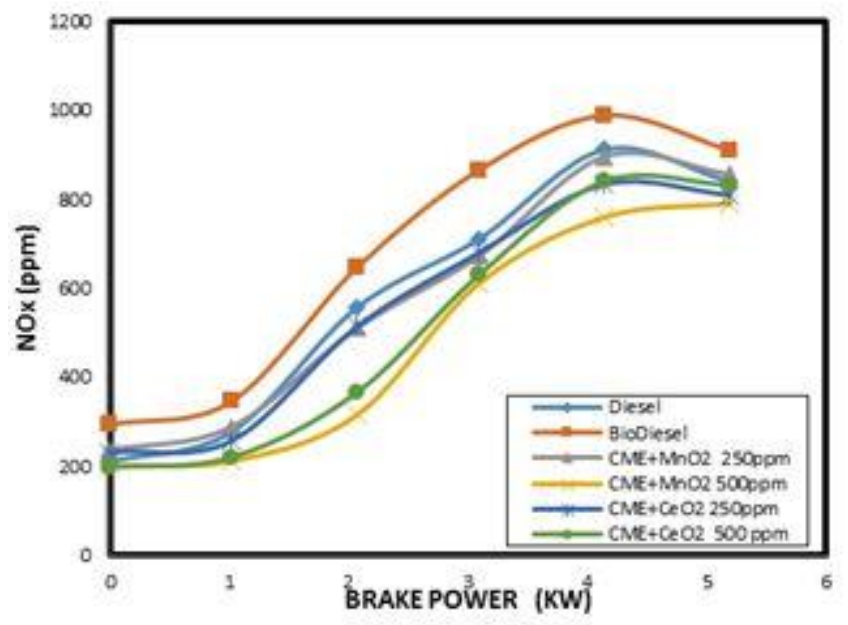

Figure 5. Variation of NOx with BP for various biodiesel blends.

The emanation of carbon monoxide $(\mathrm{CO})$ requires a temperature of 1200 o $\mathrm{C}$ to create $\mathrm{CO} 2$ by oxidation. Figure 4 exhibits the carbon monoxide (CO) floods versus different dosing dimension of $\mathrm{CeO} 2$ and $\mathrm{MnO} 2$ with cotton seed methyl ester bio fuel. $\mathrm{CeO} 2$ and $\mathrm{MnO} 2$ nano-particles with improvement estimations of 250 and 500 ppm diminished the $\mathrm{CO}$ floods of the cotton seed methyl ester fuel. $\mathrm{CO}$ discharge decay as appeared by CSME fuel result is $12.2 \%$ and $13.1 \%$ for the reasonable powers at the nanoparticle advancement estimations of 250 and 500 ppm CeO2, 16.4\% and $15.9 \%$ for the 250 and 500 ppm MnO2 autonomously. The commonplace $\mathrm{CO}$ overflowing reduction is $10.2 \%$ and $7.6 \%$ for the balanced fills at the nanoparticle expansion segment of 250 and 500 ppm $\mathrm{CeO} 2,3 \%$ and $1 \%$ for the 25 and $50 \mathrm{ppm} \mathrm{MnO} 2$ freely. The best run of the mill $\mathrm{CO}$ decrease is $10.2 \%$ as appeared base fuel at the expansion segment of $250 \mathrm{ppm} \mathrm{CeO} 2$.

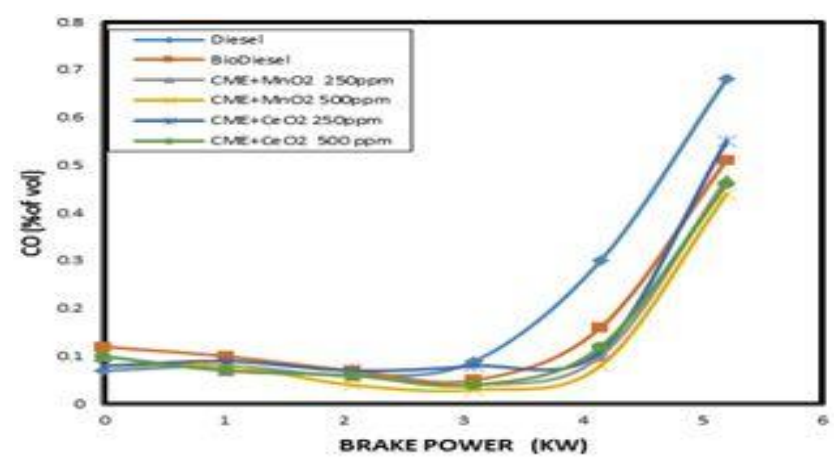

Figure 6. Variation of $\mathrm{CO}$ with $\mathrm{BP}$ for various biodiesel blends

Published By:

Blue Eyes Intelligence Engineering DOI:10.35940/ijeat.A1061.1291S419 


\section{CONCLUSIONS}

Following are the real ends drawn from the trial work directed with biodiesel and two various nanoparticle fuel included substances specifically $\mathrm{MnO} 2$ and $\mathrm{CeO} 2$ were added to biodiesel at the alternative estimation of 250 and 500ppm.

- $\quad$ The brake thermal efficiency (BTE) of the diesel motor is improved by the development of manganese oxide in the biofuel.

- Higher fuel utilization biofuel is at higher engine speed and diminished SFC by expanded in Brake control.

- A critical decrease in Hydrocarbon (HC) surge is seen by extension of the additional metal oxides with biodiesel fuel.

- NOx outflow was diminished on the extension of cerium oxide nano-particles to biodiesel.

- Both metal oxides with present of biodiesel are altogether decreased the $\mathrm{CO}$ discharge at higher burden $\mathrm{CO}$ outflow expanded.

\section{REFERENCES}

1. M. Guru, U. Karakaya, D. Altiparmak, and A. Alicilar (2002) "Improvement of Diesel fuel properties by using additives,"Energy Conversion and Management, vol. 43, no. 8, pp. 1021-1025, 2002.

2. J.M.Valentine, J.D.Peter- Hoblyn, andG.K.Acres, (2000) "Emissions reduction and improved fuel economy performance from a bimetallic platinum/cerium diesel fuel additive at ultra-low dose rates," SAE Technical Paper 2000-01-1934, 2000.

3. X. Shi, Y. Yu, H. He, S. Shuai, J. Wang, and R. Li, (2005) "Emission characteristics using methyl soyate-ethanol-diesel fuel blends on a diesel engine," Fuel, vol. 84, no. 12-13, pp. 1543-1549, 2005.

4. G. Skillas, Z. Qian, U. Baltensperger, U. Matter, and H.Burtscher, (2000) "Influence of additives on the size distribution and composition of particles produced by diesel engines," combustion Science and Technology, vol. 154, no. 1, pp. 259-273, 2000.

5. J. Lahaye, S. Boehm, P. H. Chambrion, and P. Ehrburger, (1996) "Influence of cerium oxide on the formation and oxidation of soot," Combustion and Flame, vol. 104, no. 1-2, pp. 199-207, 1996.

6. H. Jung, D. B. Kittelson, and M. R. Zachariah, (2005) "The influence of a cerium additive on ultrafine diesel particle emissions and kinetics of oxidation," Combustion and Flame, vol. 142, no. 3, pp. 276-288, 2005.

7. F.R. Cassee, E.C. Van Balen, C. Singh, D. Green, H. Muijser, J. Weinstein, K. Dreher (2010) "Exposure, health and ecological effects review of engineered nanoscale cerium and cerium oxide associated with its use as a fuel additive" Crit. Rev Toxicol. 41, 213-229.

8. V. Sajith, C.B. Sobhan, and G.P. Peterson, (2010) "Experimental Investigations on the Effects of Cerium Oxide Nanoparticle Fuel Additives on Biodiesel" Advances in Mechanical Engineering 2010:6.

9. V. Sánchez Escribano, E. Fernández López, J.M. Gallardo- Amores, C. del Hoyo Martínez, C. Pistarino, M. Panizza, C.Resini and G.Busca (2008) "A study of a ceria-zirconia-supported manganese oxide catalyst for combustion of Diesel soot particles" Combustion and Flame 153 (2008) 97-104

10. Barry Park, Kenneth Donaldson, Rodger Duffin, Lang,Tran, Frank Kelly, Ian Mudway, Jean Paul Morin, Robin Guest, Peter Jenkinson, Zissis Samaras, Myrsini Giannouli, Haris Kouridis, Patricia Martin, (2008) "Hazard and Risk assessment of a Nanoparticulate Cerium Oxide based Diesel Fuel Additive-A Case Study" Inhalation Toxicology. 20(6): 547-566.

11. W. Ying, Z. Longbao, and W. Hewu, (2006) "Diesel emission improvements by the use of oxygenated DME/diesel blend fuel" Atmospheric Environment 40:2313-2320.

12. A. Keskin, M. Guru, and D. Altiparmak, (2011), "Influence of metallic based fuel additives on performance and exhaust emissions of diesel engine" Energy Conversion and Management, 52:60-65.

13. V. Sanchez Escribano, E. Fernandez Lopez, J.M. Gallardo- Amores, Hoyo Martínez C. del, C. Pistarino, M. Panizza, C. Resini, G. Buscac (2008) "A study of a ceria-zirconia- supported manganese oxide catalyst for combustion of Diesel soot particles" Combustion and Flame. 153: 97-104.

14. Melanie Auffan, Jerome Rose, Thierry Orsiere, Michel De Meo, Antoine Thill, Ophelie Zeyons, Olivier Proux, Armand Masion, Perrine Chaurand, Olivier Spalla, Alain Botta, Mark R. Wiesner, Jeanyves Bottero. (2009) "CeO nano-particles induce DNA damage towards human dermal fibroblasts" in vitro. Nanotoxicology.DOI: 10.1080/17435390902788086.
15. V. Arul Mozhi Selvan, R.B. Anand, M. Udayakumar (2008) "Stability and Performance Characteristics of Diesohol Using Biodiesel as Additive in Compression Ignition Engine" Proc. of the Int. conference on Fascinating Advances in Mechanical Engineering, India. pp. 667-673.

\section{AUTHORS PROFILE}

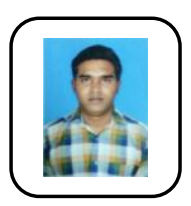

A. Pakiya pradeep, M.E., (Ph.D), Published 1 paper their publications.

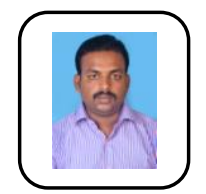

Dr. S Gowthaman, Ph.D., (IC engines), Published 11 papers in international publications, and membership in ISTE,. 